\title{
Anti-Inflammatory Effects of GLP-1-Based Therapies beyond Glucose Control
}

\author{
Young-Sun Lee ${ }^{1}$ and Hee-Sook Jun ${ }^{1,2,3}$ \\ ${ }^{1}$ Lee Gil Ya Cancer and Diabetes Institute, Gachon University, 7-45 Songdo-dong, Yeonsu-ku, Incheon 406-840, Republic of Korea \\ ${ }^{2}$ College of Pharmacy and Gachon Institute of Pharmaceutical Science, Gachon University, 7-45 Songdo-dong, Yeonsu-ku, \\ Incheon 406-840, Republic of Korea \\ ${ }^{3}$ Gachon Medical Research Institute, Gil Hospital, Incheon 405-760, Republic of Korea
}

Correspondence should be addressed to Hee-Sook Jun; hsjun@gachon.ac.kr

Received 5 February 2016; Revised 2 March 2016; Accepted 3 March 2016

Academic Editor: Joilson O. Martins

Copyright (C) 2016 Y.-S. Lee and H.-S. Jun. This is an open access article distributed under the Creative Commons Attribution License, which permits unrestricted use, distribution, and reproduction in any medium, provided the original work is properly cited.

\begin{abstract}
Glucagon-like peptide-1 (GLP-1) is an incretin hormone mainly secreted from intestinal L cells in response to nutrient ingestion. GLP-1 has beneficial effects for glucose homeostasis by stimulating insulin secretion from pancreatic beta-cells, delaying gastric emptying, decreasing plasma glucagon, reducing food intake, and stimulating glucose disposal. Therefore, GLP-1-based therapies such as GLP-1 receptor agonists and inhibitors of dipeptidyl peptidase-4, which is a GLP-1 inactivating enzyme, have been developed for treatment of type 2 diabetes. In addition to glucose-lowering effects, emerging data suggests that GLP-1-based therapies also show anti-inflammatory effects in chronic inflammatory diseases including type 1 and 2 diabetes, atherosclerosis, neurodegenerative disorders, nonalcoholic steatohepatitis, diabetic nephropathy, asthma, and psoriasis. This review outlines the anti-inflammatory actions of GLP-1-based therapies on diseases associated with chronic inflammation in vivo and in vitro, and their molecular mechanisms of anti-inflammatory action.
\end{abstract}

\section{Introduction}

Glucagon-like peptide-1 (GLP-1) is produced by posttranslational proteolytic cleavage of the proglucagon gene product and mainly secreted from the enteroendocrine $L$ cells in the distal intestine in response to nutrient ingestion. GLP-1 is an incretin hormone, which increases glucose-stimulated insulin secretion $[1,2]$. GLP-1 is quickly degraded by dipeptidyl peptidase-4 (DPP-4), and inhibition of this proteolytic enzyme enhances its biological half-life [3]. GLP-1 has many beneficial effects on the control of blood glucose levels including stimulation of insulin secretion and inhibition of glucagon secretion, expansion of the beta-cell mass by stimulating beta-cell proliferation and differentiation and inhibiting beta-cell apoptosis, delay of gastric emptying, and reduction of food intake [4-6]. Therefore, GLP-1 has been extensively studied as a possible treatment of type 2 diabetes, and GLP-1 analogues and DPP- 4 inhibitors are now widely in clinical use in these patients [7-11].
Expression of the GLP-1 receptor is widely detected in various cells and organs including the kidney, lung, heart, hypothalamus, endothelial cells, neurons, astrocytes, and microglia as well as pancreatic beta-cells [12-17], suggesting that GLP-1 might have additional roles other than glucoselowering effects. It was reported that GLP-1 shows antiinflammatory effects on pancreatic islets and adipose tissue, contributing to lowering glucose levels in diabetes [18-20]. In addition to these tissues, emerging data suggest that GLP1-based therapies also showed anti-inflammatory effects on the liver, vascular system including aorta and vein endothelial cells, brain, kidney, lung, testis, and skin by reducing the production of inflammatory cytokines and infiltration of immune cells in the tissues [17, 21-25]. Thus, GLP-1 therapy may be beneficial for the treatment of chronic inflammatory diseases including nonalcoholic steatohepatitis, atherosclerosis, neurodegenerative disorders, diabetic nephropathy, asthma, and psoriasis [14, 26-32]. Drugs which are GLP-1 receptor agonists or DPP-4 inhibitors are shown in Table 1. In 
TABLE 1: GLP-1-based drugs.

\begin{tabular}{|c|c|c|c|}
\hline GLP-1-based drugs & Generic name & Disease & References \\
\hline \multirow{16}{*}{ GLP-1 receptor agonists } & \multirow{5}{*}{ Exenatide (synthetic form of exendin-4) } & Diabetes & {$[43,46,47]$} \\
\hline & & Vascular disease & {$[61,65,70]$} \\
\hline & & Nonalcoholic steatohepatitis & {$[61,93,96]$} \\
\hline & & Nephropathy & {$[99,101,105,107]$} \\
\hline & & Neurodegenerative brain disorder & {$[87,92]$} \\
\hline & \multirow{7}{*}{ Liraglutide } & Diabetes & {$[48]$} \\
\hline & & Vascular disease & {$[8,23,58-60]$} \\
\hline & & Neurodegenerative brain disorder & {$[24,84,89]$} \\
\hline & & Nonalcoholic steatohepatitis & {$[9,28,95]$} \\
\hline & & Nephropathy & {$[14]$} \\
\hline & & Asthma & {$[30,108]$} \\
\hline & & Psoriasis & {$[31,111,112]$} \\
\hline & Lixisenatide & Neurodegenerative brain disorder & {$[90]$} \\
\hline & \multirow{3}{*}{$\begin{array}{c}\text { Albiglutide } \\
\text { Taspoglutide } \\
\text { Dulaglutide }\end{array}$} & & \\
\hline & & & \\
\hline & & & \\
\hline \multirow{14}{*}{ DPP-4 inhibitors } & \multirow{4}{*}{ Sitagliptin } & Diabetes & {$[7,19,45]$} \\
\hline & & Vascular disease & {$[26,64,65,72]$} \\
\hline & & Neurodegenerative brain disorder & {$[91]$} \\
\hline & & Nephropathy & {$[25,107]$} \\
\hline & Des-fluoro-sitagliptin & Vascular disease & {$[66]$} \\
\hline & \multirow{2}{*}{ Alogliptin } & Vascular disease & {$[67]$} \\
\hline & & Nephropathy & {$[105,106]$} \\
\hline & \multirow{2}{*}{ Linagliptin } & Nephropathy & {$[104]$} \\
\hline & & Vascular disease & {$[63]$} \\
\hline & \multirow{2}{*}{ Vildagliptin (PKF-275-055) } & Diabetes & [49] \\
\hline & & Nephropathy & {$[103]$} \\
\hline & NVP-DPP728 & Diabetes & {$[44]$} \\
\hline & Anagliptin & Nephropathy & {$[105]$} \\
\hline & Saxagliptin & Nephropathy & {$[102]$} \\
\hline
\end{tabular}

this review, we will introduce some of the chronic inflammatory diseases and then discuss evidence for beneficial effects of GLP-1-based therapies focusing on its anti-inflammatory actions.

\section{Diabetes}

Type 1 diabetes is caused by autoimmune-mediated destruction of pancreatic beta-cells [33], and type 2 diabetes is caused by both insulin resistance and relative deficiency of insulin [34-36]. Inflammation can be a mediator of insulin resistance and beta-cell damage by high glucose, fatty acids, or adipokines released from adipose tissues [37-39]. Thus, inflammation is an important factor for the pathogenesis of both type 1 and type 2 diabetes, and inhibition of inflammation can be a therapeutic strategy for treatment of diabetes.

The proinflammatory cytokines, such as interleukin-1 beta (IL-1 $\beta$ ), interferon gamma (IFN- $\gamma$ ), and tumor necrosis factor alpha (TNF- $\alpha)$, inhibit glucose-stimulated insulin secretion and proliferation of beta-cells [40-42]. Treatment 
of isolated mouse islets with palmitate induced the expression of proinflammatory cytokines TNF- $\alpha$, IL-1 $\beta$, and IL- 6 . Liraglutide (100 nM), a long-acting GLP-1 analogue, inhibited the palmitate-induced expression of these inflammatory factors and p65 expression [43]. Treatment of cultured human islets with exendin-4 (50 nM), a GLP-1 receptor agonist, suppressed the expression of inflammatory genes such as

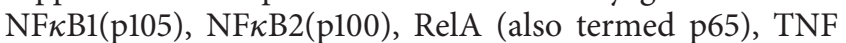
receptor superfamily member $1 \mathrm{~A}$, and receptor-interacting serine/threonine kinase 2. As well, exendin-4 (50 nM) and cyclic adenosine monophosphate (cAMP) response elementbinding protein overexpression additively protected transplanted human islets in streptozotocin- (STZ-) induced diabetic nude mice [44]. Treatment of nonobese diabetic mice with the DPP-4 inhibitor, NVP-DPP728 (30 mg/kg), significantly increased the levels of plasma transforming growth factor beta-1 (TGF- $\beta 1$ ), an anti-inflammatory cytokine, and increased CD4+CD25+FoxP3+ regulatory T cells, contributing to the remission of diabetes [45]. Treatment of dietinduced obese mice with sitagliptin $(4 \mathrm{~g} / \mathrm{kg})$, a DPP-4 inhibitor, significantly reduced the expression of inflammatory genes including monocyte chemotactic protein- (MCP-) 1, IL-6, IL-12(p40), IL-12(p35), and IFN- $\gamma$-induced protein 10 (IP-10) in pancreatic islets and improved glucosestimulated insulin secretion in isolated islets [19]. Treatment of STZ-induced diabetic rats with another DPP-4 inhibitor, vildagliptin $(10 \mathrm{mg} / \mathrm{kg})$, significantly reduced plasma TNF$\alpha$ concentration and decreased nitric oxide concentration in serum and pancreatic homogenates compared with untreated diabetic rats [46]. Treatment with sitagliptin $(20 \mathrm{mg} / \mathrm{kg})$ increased serum GLP-1 levels in STZ-induced diabetic monkeys and showed significantly protective effects on STZinduced islet injury in vivo and in vitro via activation of the insulin-like growth factor receptor (IGFR)/AKT/mammalian target of rapamycin (mTOR) signaling pathways [47]. These results suggest that GLP-1-based therapies suppress inflammatory cytokines and increase anti-inflammatory mediators in the pancreas.

C-X-C motif chemokine 10 (CXCL10/IP10), which is induced by IFN- $\gamma$, has an important role in recruiting activated $\mathrm{T}$ cells into the islets in type 1 diabetes. Exendin$4(100 \mathrm{nM})$ decreased IFN- $\gamma$-induced signal transducer and activator of transcription-1 (STAT1), which is important for CXCL10 expression in the pancreatic beta-cell line, MIN6 cells, and human islets. Therefore, suppression of CXCL10 production by exendin- 4 could reduce islet inflammation by decreasing cytotoxic T lymphocyte recruitment into the islets in autoimmune type 1 diabetes [48].

Serine proteinase inhibitor-9 plays an important role in the survival of cells against attack by natural killer cells and cytotoxic $\mathrm{T}$ lymphocytes, which play a direct role in the destruction of pancreatic beta-cells in type 1 diabetes. The GLP-1 receptor agonist, exenatide (a synthetic form of exendin-4) (10 nM), induces the expression of serine protease inhibitor-9 in human islets [49]. These results suggest that GLP-1-based therapies not only directly regulate the expression of inflammatory mediators, but also regulate the recruitment of immunocytes and protect from immunocyte attack, contributing to the preservation of pancreatic islets.
The abundance of proinflammatory cytokines and chemokines in adipose tissue is a key contributor to insulin resistance in type 2 diabetes, and blocking of inflammatory signaling pathways or immune cell infiltration in adipose tissue improves insulin sensitivity [50-52]. Administration of a recombinant adenovirus producing GLP-1 $(4 \times$ $10^{9} \mathrm{PFU} / \mathrm{mouse}$ ) to $o b / o b$ mice reduced the macrophage population and production of TNF- $\alpha$, MCP-1, and IL- 6 in adipose tissue via inhibition of nuclear factor-kappa B (NF$\kappa \mathrm{B})$ activation and phosphorylation of ERK1/2 and c-Jun N-terminal kinases [18]. Sitagliptin $(4 \mathrm{~g} / \mathrm{kg})$ also showed similar effects and reduced the expression of mRNA for inflammatory cytokine genes and macrophage infiltration in adipose tissue of high fat diet- (HFD-) induced obese mice [19]. In patients with type 2 diabetes, sitagliptin (100 mg/day) therapy significantly reduced the plasma levels of C-reactive protein (CRP), IL-6, IL-18, secreted phospholipase-A2, soluble intracellular adhesion molecule- (ICAM-) 1, and E-selectin compared with placebo. The inflammatory score and the homeostatic model assessment index for insulin resistance were significantly reduced in sitagliptin-treated type 2 diabetes patients [7]. Therefore, suppression of inflammatory mediators in adipose tissue by GLP-1-based therapies might contribute to the improvement of insulin sensitivity.

GLP-1-based therapies for diabetes contribute to reduce inflammation and have additional beneficial effects such as islet preservation and improvement of insulin sensitivity in addition to glucose-lowering effects. However, some rare cases of acute pancreatitis and neoplasms have been reported [53-55]; thus the establishment of safety of GLP-1-based therapy should be validated by sufficient further studies.

\section{Vascular Disease}

Inflammation is known to be a risk factor for vascular diseases such as atherosclerosis. Atherosclerotic cardiovascular disease is caused by proinflammatory stimuli in the vascular endothelial cells and is associated with increased plasma levels of TNF- $\alpha$, IL-6, CRP, and circulating endotoxin (i.e., lipopolysaccharide (LPS)) [56, 57]. Atherosclerosis is a chronic inflammatory condition resulting from the invasion and accumulation of white blood cells (foam cells) in the walls of arteries and therefore is a syndrome affecting arterial blood vessels [58].

GLP-1 $(5.0 \mu \mathrm{M})$ perfusion attenuates LPS-induced microvascular permeability via the cAMP protein kinase A (PKA) pathway [59]. Liraglutide $(100 \mu \mathrm{M})$ reduced the mRNA expression of adhesion molecules such as vascular cell adhesion molecule- (VCAM-) 1, ICAM-1, and E-selectin in TNF- $\alpha$ - or LPS-stimulated human aortic endothelial cells and human umbilical vein endothelial cells [60-62]. Liraglutide $(100 \mathrm{nM})$ induced phosphorylation of calcium/calmodulin-dependent protein kinase I and $5^{\prime}$ adenosine monophosphate-activated protein kinase (AMPK), and inhibition of calcium/calmodulin-dependent protein kinase kinase $\beta$ $(\mathrm{CAMKK} \beta)$ abolished the inhibitory effect of liraglutide on the expression of VCAM-1 and E-selectin. In addition, knockdown of AMPK with short hairpin AMPK RNA 
abolished the liraglutide activation of AMPK and antiinflammatory effects. These results demonstrate that the antiinflammatory effects of liraglutide in human aortic endothelial cells is dependent on activation of CAMKK $\beta$ and AMPK, which are cAMP/Ca ${ }^{2+}$ signaling pathways [60]. In addition, it was reported that liraglutide $(100 \mathrm{nM})$ inhibited TNF- $\alpha$ - or hyperglyceamia-mediated induction of plasminogen activator inhibitor type-1 in human vascular endothelial cells [23]. Exendin-4 $(50 \mu \mathrm{g} / \mathrm{kg} / \mathrm{day})$ treatment resulted in a reduction of atherosclerosis development and the number of monocytes adhering to the endothelium wall in the aortic root in western-type diet-fed APOE* 3-Leiden.CETP(E3L.CETP) mice [63].

Sitagliptin $(25 \mu \mathrm{M})$, NVP-DPP728 $(270 \mu \mathrm{M})$, or liraglutide $(1000 \mathrm{ng} / \mathrm{mL})$ treatment significantly reduced oxidizedlow-density lipoprotein-induced or PKC activator-induced protein expression of nucleotide-binding domain-like receptor with a pyrin domain 3 (NLRP3), toll-like receptor 4 (TLR4), and IL- $1 \beta$ in a human monocytic cell line, THP1 , by decreasing phosphorylated-protein kinase C (PKC) [64]. Administration of linagliptin (10 mg/kg/day), a DPP-4 inhibitor, to $\mathrm{ApoE}^{-/-}$mice, an animal model of atherosclerosis, decreased inflammatory molecule expression and macrophage infiltration in the atherosclerotic aorta [65]. Another report showed that sitagliptin $(576 \mathrm{mg} / \mathrm{kg})$ reduced plaque macrophage infiltration and matrix metallopeptidase-9 (MMP-9) levels in ApoE ${ }^{-/-}$mice [26] and increased activation of AMPK and AKT signaling pathway but inhibited MAPK and ERK1/2 signaling in aorta of $\mathrm{ApoE}^{-/-}$mice [66]. This suggests that sitagliptin has protective actions against atherosclerosis through AMPK and MAPK-dependent mechanisms. In addition, sitagliptin $(30 \mathrm{mg} / \mathrm{kg} /$ day $)$ and exenatide $(3 \mu \mathrm{g} / \mathrm{kg} / 12 \mathrm{~h})$ significantly inhibited advanced glycation end products-induced oxidative stress in aortic endothelials in high fat diet (HFD)/STZ diabetic rats by reducing endothelin-1 (ET-1) and inflammatory cytokine via RhoA/Rho-associated protein kinase (ROCK)/NF- $\kappa \mathrm{B}$ signaling pathways and AMPK activation [67]. Des-fluorositagliptin $(200 \mathrm{mg} / \mathrm{kg} /$ day $)$ treatment reduced atherosclerotic lesion formation, infiltration of macrophage and T lymphocytes, and the expression of proinflammatory cytokines within plaques in $\mathrm{ApoE}^{-/-}$mice [68]. As well, treatment with alogliptin $(20 \mathrm{mg} / \mathrm{kg} /$ day $)$, a selective DPP-4 inhibitor, showed similar anti-inflammatory effects in the injured arteries of low-density lipoprotein receptor-deficient mice [69]. Interestingly, metabolite (9-37) of GLP-1 as well as the c-terminal GLP-1 split product (28-37) also reduced plaque inflammation and stabilized atherosclerotic lesions in ApoE $^{-/-}$mice [70]. These suggest that GLP-1-based therapies have protective effects in atherosclerosis by decreasing macrophage infiltration in atherosclerotic lesions via inhibition of the expression of adhesion molecules.

The loss of sirtuin 6 (SIRT6), which regulates proinflammatory mediators, in human umbilical vein endothelial cells is associated with upregulation of the expression of proinflammatory genes [71]. Liraglutide $(100 \mathrm{nM})$ treatment increased SIRT6 expression and reduced NF- $\kappa$ B expression compared with only high glucose-treated endothelial cells.
In diabetic patients treated with GLP-1-based therapy, the protein level of SIRT6 in asymptomatic plaques was significantly increased and TNF- $\alpha$ and MMP-9 levels in lesions were significantly reduced compared with diabetic patients without treatment [8]. This result suggests that GLP-1-based therapy has anti-inflammatory effects by induction of SIRT6 expression in endothelial cells.

Cardiovascular disease is increased in type 2 diabetes, and hyperglyceamia is a critical promoter during the development of cardiovascular diseases. Inflammation is an important pathophysiologic factor in diabetic cardiomyopathy. Exendin-4 protects against cardiac contractile dysfunction in an experimental myocardial infarction model. Exendin$4(5 \mu \mathrm{g} / \mathrm{kg}$ or 1 and $10 \mathrm{nM})$ inhibited high mobility group box I protein expression, a proinflammatory mediator, in myocardial ischemia and reperfusion in rats [72] and in high glucose-induced myocardial cell injury [73]. Sitagliptin (30 and $50 \mathrm{mg} / \mathrm{kg} /$ day) reduced the expression of TNF- $\alpha$ and IL- 6 in the diabetic heart and had a myocardial protective effect in STZ/HFD-induced diabetic rats [74]. Therefore, GLP-1-based therapy have anti-inflammatory effects on vascular disease and may explain the vasoprotective properties.

\section{Neurodegenerative Brain Disorder}

Neurodegenerative central nervous system disorders are associated with chronic neuroinflammation [75-77]. Epidemiological and clinical studies have suggested a link between type 2 diabetes and Alzheimer's disease [78]. In patients with Alzheimer's disease, insulin receptors and insulin signaling in the brain are desensitized and impaired as found in type 2 diabetes patients. Therefore, drugs used for treatment of diabetes are expected to have a preventive effect against Alzheimer's disease. GLP-1 is known to be produced in the brain [79] and has many functions including neuroprotection [80-82]. In addition, GLP-1 and GLP-1 analogues enter the brain through blood brain barrier [8386].

The glia may play a critical role in the central nervous system inflammatory responses including Alzheimer's disease, and GLP-1 receptor was observed in astrocytes and microglia $[17,87]$. In astrocytes, GLP-1 $(1 \mu \mathrm{M})$ prevented the LPS-induced IL-1 $\beta$ expression by increase of cAMP [17].

Models of Alzheimer's disease include intracerebroventricular injection of STZ [88], intracerebral injection of LPS [88], and the APPSWE/PS1 $\triangle E 9$ mouse [84]. Exenatide $(20 \mu \mathrm{g} / \mathrm{kg} /$ day $)$ treatment inhibited brain TNF- $\alpha$ levels, which were induced by intracerebroventricular injection of STZ [89]. GLP-1 (7-36) amide (50 nM) protected the synaptic impairments induced by intracerebral injection of LPS in the rat hippocampus [90]. Liraglutide $(25 \mathrm{nmol} / \mathrm{kg} /$ day) treatment significantly reduced the inflammatory response in the cortex as measured by the number of activated microglia and prevented degenerative processes in a 7-month-old $\mathrm{APP}_{\mathrm{SWE}} / \mathrm{PS}_{\triangle \mathrm{E} 9}$ mouse model of Alzheimer's disease [86]. In addition, in the 14-month-old $\mathrm{APP}_{\mathrm{SWE}} / \mathrm{PS1}_{\triangle \mathrm{E} 9}$ mouse, inflammation was also markedly reduced and restorative effects were improved by liraglutide treatment [91]. The GLP-1 receptor agonist, lixisenatide, exerted neuroprotective 
effects via reduction of oxidative stress and the chronic inflammation response in the brain of $\mathrm{APP}_{\mathrm{SWE}} / \mathrm{PS}_{\triangle \mathrm{Eg}}$ mouse [92]. In addition, sitagliptin (10 and $20 \mathrm{mg} / \mathrm{kg}$ ) also showed similar anti-inflammatory effects in $\mathrm{APP}_{\mathrm{SWE}} / \mathrm{PS1}_{\triangle \mathrm{E} 9}$ mouse [93]. This suggests that GLP-1-based therapies could have a preventive and restorative effect on the pathophysiology of Alzheimer's disease progression.

Irradiation of the brain causes a chronic inflammatory response. X-ray irradiation of the brain significantly increased IL-6, IL-1 $\beta$, and IL-12p70 cytokine protein expression. Liraglutide $(25 \mathrm{nmol} / \mathrm{kg} /$ day $)$ treatment reduced the mRNA expression of proinflammatory cytokine genes, which was induced by X-ray irradiation [24].

Parkinson's disease is a chronic and neurodegenerative brain disorder, and inflammatory activity is one of important features of Parkinson's disease. Microglial activation plays a critical role in the pathogenesis of the 1-methyl-4-phenyl1,2,3,6-tetrahydropyidine- (MPTP-) induced Parkinson's disease model and human Parkinson's disease [27]. Exendin-4 $(10 \mu \mathrm{g} / \mathrm{kg})$ treatment significantly decreased MPTP-induced microglial activation and suppressed MPTP-induced expression of TNF- $\alpha$ and IL-1 $\beta$ [94]. The inhibitory effect of exendin- 4 on microglial activation may have therapeutic potential for the treatment of Parkinson's disease. These anti-inflammatory effects of GLP-1-based therapies on the brain may protect against neurodegenerative central nervous system disorders.

\section{Nonalcoholic Steatohepatitis}

Nonalcoholic steatohepatitis is associated with an inflammation of the liver by an aberrant accumulation of fat in the liver. GLP-1 receptor agonists reduced alanine aminotransferase and aspartate aminotransferase levels in patients with nonalcoholic fatty liver disease (or type 2 diabetes) and improved lipid metabolism and reduced fat mass [21]. Liraglutide $(50,100$, and $200 \mu \mathrm{g} / \mathrm{kg} / 12 \mathrm{~h}$ ) treatment protected against nonalcoholic fatty liver disease by inhibition of ER stress-associated apoptosis in HFD-fed rats [28]. Liraglutide or exendin-4 $(1 \mathrm{nmol} / \mathrm{kg} /$ day $)$ treatment dose-dependently reduced steatosis and lobular inflammation in HFD-fed rats or mice compared with the saline-injected group [28, 95], probably due to an increase of SIRT1 [96]. As a matter of fact, exendin-4 $(50 \mu \mathrm{g} / \mathrm{kg} / \mathrm{day})$ treatment increased the expression of SIRT1 and its downstream factor, AMPK, in exendin-4 treated mouse livers and hepatocytes. Exendin- 4 treatment reduced hepatic expression of the inflammatory markers TNF- $\alpha$, IL- $1 \beta$, and IL- 6 and macrophage markers, cluster of differentiation 68 (CD68), and F4/80 in the liver of mice fed a western-type diet [63].

In nonalcoholic steatohepatitis patients with glucose intolerance, liraglutide $(0.9 \mathrm{mg} /$ person/day) therapy for 96 weeks resulted in improvement of histological indicators of inflammation in seven subjects out of ten subjects [97]. CRP is produced by the liver and is a marker of inflammation. In a retrospective analysis of 110 obese patients with type 2 diabetes treated with liraglutide, the mean concentration of CRP declined after treatment with liraglutide for a mean duration of 7.5 months [9]. In addition, exenatide plus metformin resulted in a significant reduction in CRP and TNF- $\alpha$ compared with baseline [98]. These reports suggest that GLP-1-based therapies improve fatty liver disease by ameliorating inflammation in rodents and humans.

\section{Nephropathy}

Diabetic nephropathy is associated with a state of lowgrade inflammation in the microvasculature of the kidney's glomeruli $[99,100]$. The GLP-1 receptor is expressed in glomerular capillaries and vascular walls of the mouse kidney $[14,101]$ and in the glomerulus and proximal convoluted tubules of the rat and pig [29, 102]. GLP-1 receptor deficiency in the diabetic nephropathy-resistant C57BL/6-Akita mouse contributes to the development of diabetic nephropathy, and liraglutide treatment suppressed the progression of nephropathy of the KK/Ta-Akita mouse, which shows high susceptibility to diabetic nephropathy [14], suggesting that GLP-1 action might play an important role in prevention of diabetic nephropathy.

Various studies have shown that GLP-1-based therapies can reduce macrophage infiltration and inflammatory molecules in models of diabetic nephropathy. Exendin-4 ( 3 and $10 \mu \mathrm{g} / \mathrm{kg} /$ day) treatment significantly downregulated the gene expression of CD14, ICAM-1, and TGF $\beta 1$ in the renal cortex, prevented glomerular macrophage infiltration in glomeruli, and reduced oxidative stress and inflammation in tubular cells in STZ-induced diabetic animals $[101,103]$. Treatment with the DPP-4 inhibitor, saxagliptin $(10 \mathrm{mg} / \mathrm{kg} /$ day $)$, reduced renal tubulointerstitial inflammation by NF- $\kappa$ Bp 65 -mediated macrophage infiltration in STZinduced diabetic enos ${ }^{-1-}$ mice [104]. Administration of the DPP-4 inhibitor, PKF275-055 (3 mg/kg/day), or linagliptin in STZ-induced diabetic rats inhibited macrophage infiltration, inflammatory molecules, and NF- $\kappa \mathrm{B}$ activity in the glomeruli [105] and significantly reduced glomerular leukocyte infiltration [106]. Sitagliptin $(10 \mathrm{mg} / \mathrm{kg} /$ day $)$ treatment decreased the expression of proinflammatory cytokine genes IL-1 $\beta$ and TNF- $\alpha$ in kidney of diabetic ZDF rat [25].

GLP-1-based therapies are also effective in nondiabetic models of kidney injury. In a nondiabetic glomerular injury model, alogliptin $(20 \mathrm{mg} / \mathrm{kg} /$ day $)$, anagliptin $(300 \mathrm{mg} / \mathrm{kg} /$ day), or exendin-4 $(10 \mathrm{mg} / \mathrm{kg})$ significantly reduced infiltration of CD68-positive inflammatory macrophages in the kidney [107]. In the mouse cisplatin-induced renal injury model, treatment with alogliptin $(10 \mathrm{mg} / \mathrm{kg} /$ day $)$ significantly decreased cisplatin-induced renal injury via antiapoptotic effects [108]. In addition, after ischemia-reperfusion injury, the expression of proinflammatory cytokines, NF- $\kappa \mathrm{B}$ and ICAM-1, as well as macrophage infiltration in the kidney was significantly decreased by exendin $-4(10 \mu \mathrm{g} / \mathrm{kg})$ or sitagliptin $(600 \mathrm{mg} / \mathrm{kg})$ treatment [109]. Therefore, GLP-1based therapies might be beneficial for nephropathy by reducing glomerular leukocyte infiltration and proinflammatory mediators. 


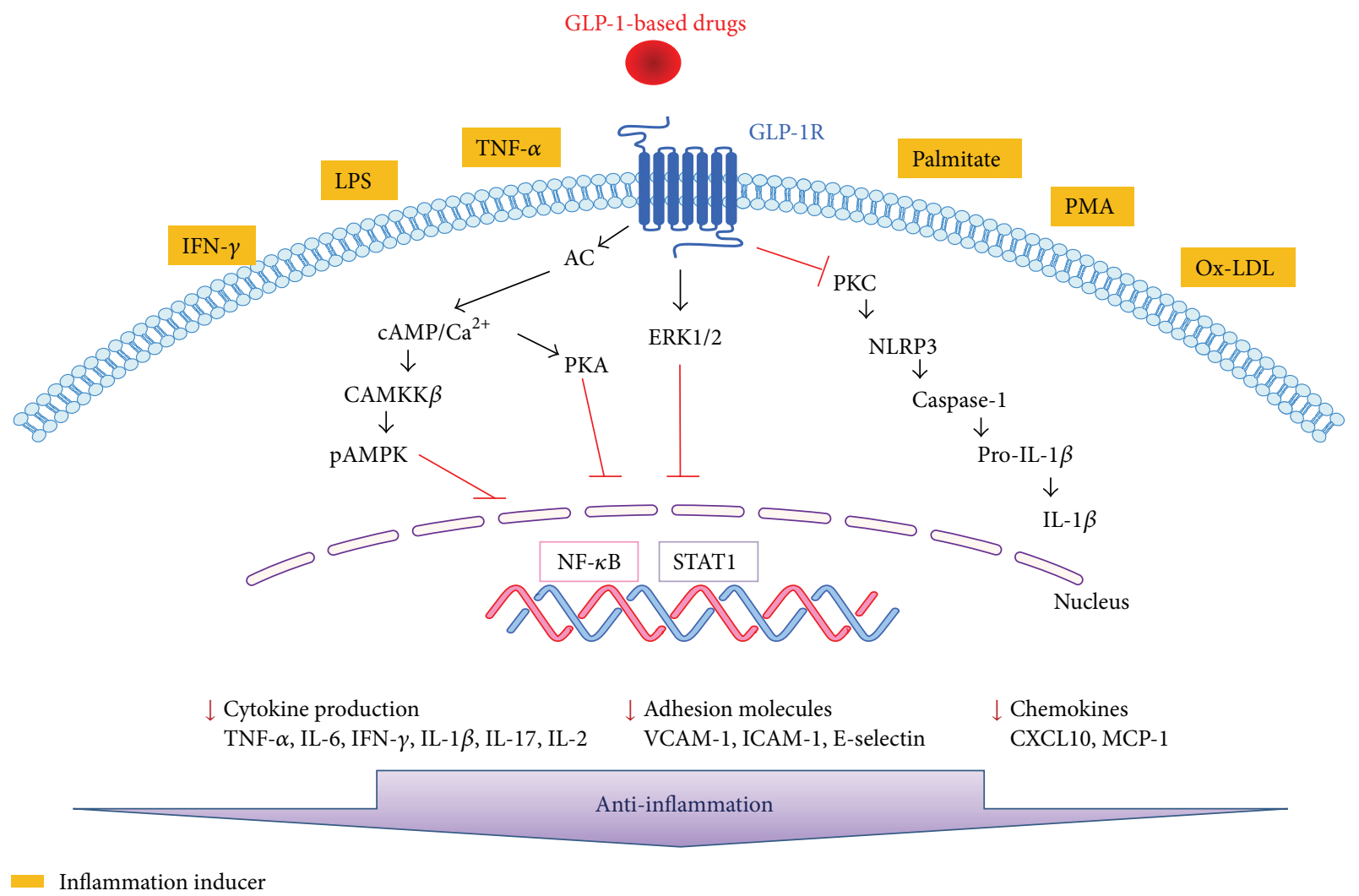

FIGURE 1: Molecular signals underlying the anti-inflammatory effects of GLP-1-based drugs. DPP-4 inhibitors increase GLP-1 levels in plasma. GLP-1 and GLP-1 receptor (GLP-1R) agonists bind to the GLP-1 receptor, which blocks PKC or NF- $\kappa$ B activation and subsequent expression of NLRP3, IL-1 $\beta$, TNF- $\alpha$, IL-6, VCAM-1, IFN- $\gamma$, and MCP-1. In addition, GLP-1R signaling activates cAMP/Ca ${ }^{2+}$, CAMKK $\beta$, and pAMPK, which induces anti-inflammatory effects on monocyte adhesion.

\section{Other Diseases}

Asthma is a chronic pulmonary inflammatory disease. Liraglutide $(2 \mathrm{mg} / \mathrm{kg})$ reduced immune cell infiltration and protein expression of E-selectin, TNF- $\alpha$, IL-4, IL-5, and IL-13 in the lung tissue or bronchoalveolar lavage fluid in an ovalbumin-induced chronic asthma model. Liraglutide treatment decreased NF- $\kappa \mathrm{B}$ activation, which was reversed by PKA inhibitor, H-89, suggesting that the cAMP-PKA pathway is involved in inhibition of NF- $\kappa \mathrm{B}$ activation, and subsequently the inhibition of inflammation [110]. In addition, in mice with bleomycin-induced pulmonary fibrosis, liraglutide treatment inhibited infiltration of immune cells and decreased the content of TGF- $\beta 1$. Liraglutide treatment markedly attenuated bleomycin-induced VCAM-1 and NF$\kappa \mathrm{B}$ activation [30]. These results suggest that GLP-1-based therapies might have beneficial effects on asthma but need to be validated by clinical studies.

Obesity can reduce the quality and count of men's sperm $[111,112]$. The expression of TNF- $\alpha$, MCP-1, and F4/80 mRNA levels is increased in the testis and significantly decreased the sperm motility and activity in diet-induced obesity mice, and exenatide $(24 \mathrm{nmol} / \mathrm{kg} /$ day $)$ treatment suppressed the expression of TNF- $\alpha$, MCP-1, and F4/80 mRNA levels in testis and improved sperm quality in diet-induced obesity mice [111].
In type 2 diabetes patients, GLP-1 and liraglutide also improve clinical symptoms of psoriasis, a skin inflammatory disease, by downregulation of invariant natural killer T cells $[31,113,114]$.

GLP-1 (100 nM) or exendin-4 (10 nM) treatment inhibited TNF- $\alpha$-induced expression of receptor for advanced glycation end products (RAGE), ICAM-1, and VCAM-1 in human retinal pigment epithelial cells [32], suggesting that GLP1-based therapies might have beneficial effects on diabetic retinopathy.

Treatment with the DPP-4 inhibitors, linagliptin ( $5 \mathrm{mg} / \mathrm{kg} /$ day) and sitagliptin $(50 \mathrm{mg} / \mathrm{kg} /$ day), and the GLP-1 analogue, liraglutide $(200 \mu \mathrm{g} / \mathrm{kg} / \mathrm{day})$, significantly reduced inflammatory markers such as inducible NO synthase, cyclooxygenase, and VCAM-1 via the AMPK pathway in LPS-induced endotoxemic shock in rats as a model of human sepsis [115].

These reports suggest that GLP-1-based therapies have anti-inflammatory effects in the lung, testis, skin, and eye.

\section{Conclusion}

Inflammation is a protective process including immune system, vascular system, and molecular mediators. However out-of-control inflammation and chronic inflammation can 


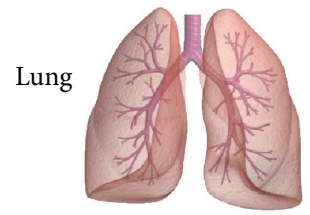

Asthma:

TNF- $\alpha$, IL-4, IL-5, IL-13 $\downarrow$

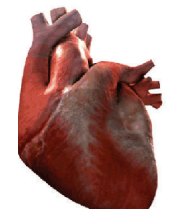

Atherosclerosis cardiovascular disease: NOS-2, COX-2, VCAM-1, TNF- $\alpha$, IL-6, PAI- $1 \downarrow$

Vascular system

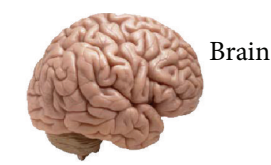

Alzheimer's disease,

Parkinson's disease:

TNF- $\alpha$, IL- $1 \beta$, IL-6 $\downarrow$
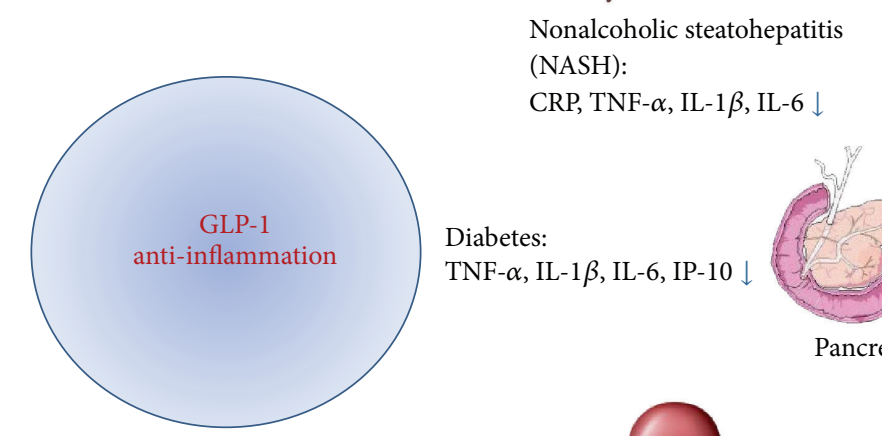

CRP, TNF- $\alpha$, IL- $1 \beta$, IL-6 $\downarrow$

Diabetes:

TNF- $\alpha$, IL- $1 \beta$, IL-6, IP-10 $\downarrow$

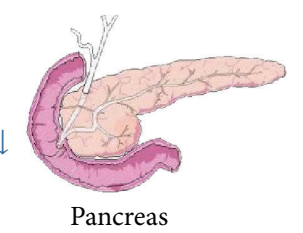

Pancreas

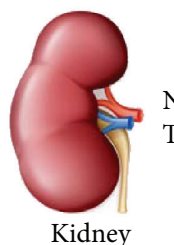

Nephropathy:

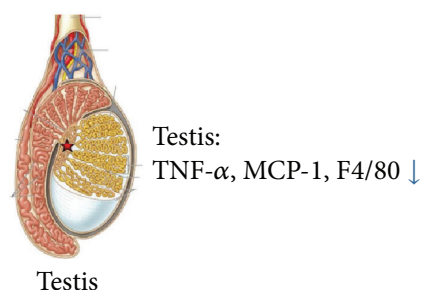

Kidney NF- $\alpha$, IL- $1 \beta$, ICAM- $1 \downarrow$

Figure 2: GLP-1-based therapies, including GLP-1, GLP-1R agonists and DPP-4 inhibitors, have anti-inflammatory functions in several organs.

cause pathological disease. Inflammation is a risk factor for diabetes, atherosclerosis, cardiovascular disease, neurodegenerative central nervous system disorders, nonalcoholic steatohepatitis, and nephropathy.

GLP-1-based therapies have many attractive and beneficial effects including their antidiabetic actions on pancreatic beta-cells. However, beyond their metabolic effects, GLP-1based therapies have been shown to have anti-inflammatory effects via several molecular pathways (Figure 1) in several organs, tissues, and cells (Figure 2). GLP-1-based therapies downregulate proinflammatory responses in inflammatory related diseases. This review concludes that GLP-1-based therapy has beneficial effects on inflammatory disease. Thus GLP-1, GLP-1R agonists, and DPP-4 inhibitors might have important roles as mediators of inflammation.

\section{Abbreviations}

AMPK: $\quad 5^{\prime}$ adenosine monophosphate-activated protein kinase

CAMKK $\beta$ : Calcium/calmodulin-dependent protein kinase kinase $\beta$

CD: $\quad$ Cluster of differentiation

CRP: $\quad$ C-reactive protein

CXCL10: C-X-C motif chemokine 10

cAMP: Cyclic adenosine monophosphate

DPP-4: Dipeptidyl peptidase-4
Erk: Extracellular signal-regulated kinase

GLP-1: Glucagon-like peptide-1

HFD: High fat diet

ICAM: Intercellular adhesion molecule

IFN: Interferon

IL: Interleukin

LPS: Lipopolysaccharide

MCP-1: Monocyte chemotactic protein

MPTP: 1-Methyl-4-phenyl-1,2,3,6tetrahydropyidine

NF- $\kappa$ B: Nuclear factor-kappa B

NLRP3: Nucleotide-binding domain-like receptor with a pyrin domain 3

PKA: Protein kinase A

PKC: $\quad$ Protein kinase C

SIRT: Sirtuin

STZ: Streptozotocin

TLR4: Toll-like receptor 4

TGF- $\beta$ : Transforming growth factor beta

TNF- $\alpha$ : Tumor necrosis factor alpha

VCAM: Vascular cell adhesion molecule.

\section{Competing Interests}

The authors declare that there are no competing interests regarding the publication of this paper. 


\section{Acknowledgments}

This research was supported by Basic Science Research Program through the National Research Foundation of Korea (NRF) funded by the Ministry of Education (2015R1D1A1A01060232). The authors thank Dr. Ann Kyle for editorial assistance.

\section{References}

[1] C. Ørskov, L. Rabenhøj, A. Wettergren, H. Kofod, and J. J. Holst, "Tissue and plasma concentrations of amidated and glycineextended glucagon-like peptide I in humans," Diabetes, vol. 43, no. 4, pp. 535-539, 1994.

[2] L. L. Kjems, J. J. Holst, A. Vølund, and S. Madsbad, "The influence of GLP-1 on glucose-stimulated insulin secretion: effects on $\beta$-cell sensitivity in type 2 and nondiabetic subjects," Diabetes, vol. 52, no. 2, pp. 380-386, 2003.

[3] R. Mentlein, B. Gallwitz, and W. E. Schmidt, "Dipeptidylpeptidase IV hydrolyses gastric inhibitory polypeptide, glucagon-like peptide-1(7-36)amide, peptide histidine methionine and is responsible for their degradation in human serum," European Journal of Biochemistry, vol. 214, no. 3, pp. 829-835, 1993.

[4] Y.-S. Lee and H.-S. Jun, "Anti-diabetic actions of glucagon-like peptide-1 on pancreatic beta-cells," Metabolism: Clinical and Experimental, vol. 63, no. 1, pp. 9-19, 2014.

[5] M. Karaca, C. Magnan, and C. Kargar, "Functional pancreatic beta-cell mass: involvement in type 2 diabetes and therapeutic intervention," Diabetes \& Metabolism, vol. 35, no. 2, pp. 77-84, 2009.

[6] D. J. Drucker, “The biology of incretin hormones," Cell Metabolism, vol. 3, no. 3, pp. 153-165, 2006.

[7] A. J. Tremblay, B. Lamarche, C. F. Deacon, S. J. Weisnagel, and P. Couture, "Effects of sitagliptin therapy on markers of low-grade inflammation and cell adhesion molecules in patients with type 2 diabetes," Metabolism: Clinical and Experimental, vol. 63, no. 9, pp. 1141-1148, 2014.

[8] M. L. Balestrieri, M. R. Rizzo, M. Barbieri et al., "Sirtuin 6 expression and inflammatory activity in diabetic atherosclerotic plaques: effects of incretin treatment," Diabetes, vol. 64, no. 4, pp. 1395-1406, 2015.

[9] A. Varanasi, P. Patel, A. Makdissi, S. Dhindsa, A. Chaudhuri, and P. Dandona, "Clinical use of liraglutide in type 2 diabetes and its effects on cardiovascular risk factors," Endocrine Practice, vol. 18, no. 2, pp. 140-145, 2012.

[10] A. J. Garber, "Long-acting glucagon-like peptide 1 receptor agonists: a review of their efficacy and tolerability," Diabetes Care, vol. 34, supplement 2, pp. S279-S284, 2011.

[11] M. Nauck, "Incretin therapies: highlighting common features and differences in the modes of action of glucagon-like peptide1 receptor agonists and dipeptidyl peptidase-4 inhibitors," Diabetes, Obesity \& Metabolism, vol. 18, no. 3, pp. 203-216, 2016.

[12] M. Arakawa, T. Mita, K. Azuma et al., "Inhibition of monocyte adhesion to endothelial cells and attenuation of atherosclerotic lesion by a glucagon-like peptide-1 receptor agonist, exendin-4," Diabetes, vol. 59, no. 4, pp. 1030-1037, 2010.

[13] B. Thorens, "Expression cloning of the pancreatic $\beta$ cell receptor for the gluco- incretin hormone glucagon-like peptide 1," Proceedings of the National Academy of Sciences of the United States of America, vol. 89, no. 18, pp. 8641-8645, 1992.
[14] H. Fujita, T. Morii, H. Fujishima et al., "The protective roles of GLP-1R signaling in diabetic nephropathy: possible mechanism and therapeutic potential," Kidney International, vol. 85, no. 3, pp. 579-589, 2014.

[15] M. Romaní-Pérez, V. Outeiriño-Iglesias, M. Gil-Lozano, L. C. González-Matías, F. Mallo, and E. Vigo, "Pulmonary GLP1 receptor increases at birth and exogenous GLP-1 receptor agonists augmented surfactant-protein levels in litters from normal and nitrofen-treated pregnant rats," Endocrinology, vol. 154, no. 3, pp. 1144-1155, 2013.

[16] R. Goke, P. J. Larsen, J. D. Mikkelsen, and S. P. Sheikh, "Distribution of GLP-1 binding sites in the rat brain: evidence that exendin-4 is a ligand of brain GLP-1 binding sites," The European Journal of Neuroscience, vol. 7, no. 11, pp. 2294-2300, 1995.

[17] T. Iwai, S. Ito, K. Tanimitsu, S. Udagawa, and J.-I. Oka, "Glucagon-like peptide-1 inhibits LPS-induced IL-1 $\beta$ production in cultured rat astrocytes," Neuroscience Research, vol. 55, no. 4, pp. 352-360, 2006.

[18] Y.-S. Lee, M.-S. Park, J.-S. Choung et al., "Glucagon-like peptide-1 inhibits adipose tissue macrophage infiltration and inflammation in an obese mouse model of diabetes," Diabetologia, vol. 55, no. 9, pp. 2456-2468, 2012.

[19] A. D. Dobrian, Q. Ma, J. W. Lindsay et al., "Dipeptidyl peptidase IV inhibitor sitagliptin reduces local inflammation in adipose tissue and in pancreatic islets of obese mice," The American Journal of Physiology_Endocrinology and Metabolism, vol. 300, no. 2, pp. E410-E421, 2011.

[20] C. Cabou and R. Burcelin, "GLP-1, the gut-brain, and brainperiphery axes," Review of Diabetic Studies, vol. 8, no. 3, pp. 418431, 2011.

[21] X.-C. Wang, A. M. Gusdon, H. Liu, and S. Qu, "Effects of glucagon-like peptide-1 receptor agonists on non-alcoholic fatty liver disease and inflammation," World Journal of Gastroenterology, vol. 20, no. 40, pp. 14821-14830, 2014.

[22] M. Blandino-Rosano, G. Perez-Arana, J. M. Mellado-Gil, C. Segundo, and M. Aguilar-Diosdado, "Anti-proliferative effect of pro-inflammatory cytokines in cultured $\beta$ cells is associated with extracellular signal-regulated kinase $1 / 2$ pathway inhibition: protective role of glucagon-like peptide -1," Journal of Molecular Endocrinology, vol. 41, no. 1-2, pp. 35-44, 2008.

[23] H. Liu, A. E. Dear, L. B. Knudsen, and R. W. Simpson, "A longacting glucagon-like peptide-1 analogue attenuates induction of plasminogen activator inhibitor type-1 and vascular adhesion molecules," The Journal of Endocrinology, vol. 201, no. 1, pp. 5966, 2009.

[24] V. Parthsarathy and C. Hölscher, "The type 2 diabetes drug liraglutide reduces chronic inflammation induced by irradiation in the mouse brain," European Journal of Pharmacology, vol. 700, no. 1-3, pp. 42-50, 2013.

[25] C. Marques, C. Mega, A. Gonçalves et al., "Sitagliptin prevents inflammation and apoptotic cell death in the kidney of type 2 diabetic animals," Mediators of Inflammation, vol. 2014, Article ID 538737, 15 pages, 2014.

[26] F. Vittone, A. Liberman, D. Vasic et al., "Sitagliptin reduces plaque macrophage content and stabilises arteriosclerotic lesions in Apoe ${ }^{-/-}$mice," Diabetologia, vol. 55, no. 8, pp. 22672275, 2012.

[27] M. Vila, V. Jackson-Lewis, C. Guégan et al., "The role of glial cells in Parkinson's disease," Current Opinion in Neurology, vol. 14, no. 4, pp. 483-489, 2001. 
[28] N. Ao, J. Yang, X. Wang, and J. Du, "Glucagon-like peptide-1 preserves non-alcoholic fatty liver disease through inhibition of the endoplasmic reticulum stress-associated pathway," Hepatology Research, 2015.

[29] R. O. Crajoinas, F. T. Oricchio, T. D. Pessoa et al., "Mechanisms mediating the diuretic and natriuretic actions of the incretin hormone glucagon-like peptide-1," The American Journal of Physiology-Renal Physiology, vol. 301, no. 2, pp. F355-F363, 2011.

[30] S. Gou, T. Zhu, W. Wang, M. Xiao, X.-C. Wang, and Z.-H. Chen, "Glucagon like peptide-1 attenuates bleomycin-induced pulmonary fibrosis, involving the inactivation of NF- $\kappa \mathrm{B}$ in mice," International Immunopharmacology, vol. 22, no. 2, pp. 498-504, 2014.

[31] A. E. Hogan, A. M. Tobin, T. Ahern et al., "Glucagon-like peptide-1 (GLP-1) and the regulation of human invariant natural killer T cells: lessons from obesity, diabetes and psoriasis," Diabetologia, vol. 54, no. 11, pp. 2745-2754, 2011.

[32] M. Dorecka, K. Siemianowicz, T. Francuz et al., "Exendin-4 and GLP-1 decreases induced expression of ICAM-1, VCAM-1 and RAGE in human retinal pigment epithelial cells," Pharmacological Reports, vol. 65, no. 4, pp. 884-890, 2013.

[33] J.-W. Yoon and H.-S. Jun, "Autoimmune destruction of pancreatic $\beta$ cells," American Journal of Therapeutics, vol. 12, no. 6, pp. 580-591, 2005.

[34] C. R. Kahn, "Banting lecture: insulin action, diabetogenes, and the cause of type II diabetes," Diabetes, vol. 43, no. 8, pp. 10661084, 1994.

[35] G. M. Reaven, "Banting lecture 1988. Role of insulin resistance in human disease," Diabetes, vol. 37, no. 12, pp. 1595-1607, 1988.

[36] S. I. Taylor, D. Accili, and Y. Imai, "Insulin resistance or insulin deficiency. Which is the primary cause of NIDDM?" Diabetes, vol. 43, no. 6, pp. 735-740, 1994.

[37] S. Cernea and M. Dobreanu, "Diabetes and beta cell function: from mechanisms to evaluation and clinical implications," Biochemia Medica, vol. 23, no. 3, pp. 266-280, 2013.

[38] P. A. Halban, K. S. Polonsky, D. W. Bowden et al., “ $\beta$-Cell failure in type 2 diabetes: postulated mechanisms and prospects for prevention and treatment," Diabetes Care, vol. 37, no. 6, pp. 17511758, 2014.

[39] M. Cnop, N. Welsh, J.-C. Jonas, A. Jörns, S. Lenzen, and D. L. Eizirik, "Mechanisms of pancreatic $\beta$-cell death in type 1 and type 2 diabetes: many differences, few similarities," Diabetes, vol. 54, supplement 2, pp. S97-S107, 2005.

[40] I. L. Campbell, A. Iscaro, and L. C. Harrison, "IFN- $\gamma$ and tumor necrosis factor- $\alpha$ : cytotoxicity to murine islets of Langerhans," Journal of Immunology, vol. 141, no. 7, pp. 2325-2329, 1988.

[41] C. Park, J.-R. Kim, J.-K. Shim et al., "Inhibitory effects of streptozotocin, tumor necrosis factor- $\alpha$, and interleukin- $1 \beta$ on glucokinase activity in pancreatic islets and gene expression of GLUT2 and glucokinase," Archives of Biochemistry and Biophysics, vol. 362, no. 2, pp. 217-224, 1999.

[42] M. Y. Donath, J. A. Ehses, K. Maedler et al., "Mechanisms of $\beta$ cell death in type 2 diabetes," Diabetes, vol. 54, supplement 2, pp. S108-S113, 2005.

[43] C. Huang, L. Yuan, and S. Cao, "Endogenous GLP-1 as a key self-defense molecule against lipotoxicity in pancreatic islets," International Journal of Molecular Medicine, vol. 36, no. 1, pp. 173-185, 2015.

[44] K. Velmurugan, A. N. Balamurugan, G. Loganathan, A. Ahmad, B. J. Hering, and S. Pugazhenthi, "Antiapoptotic actions of exendin- 4 against hypoxia and cytokines are augmented by CREB," Endocrinology, vol. 153, no. 3, pp. 1116-1128, 2012.

[45] L. Tian, J. Gao, J. Hao et al., "Reversal of new-onset diabetes through modulating inflammation and stimulating $\beta$-cell replication in nonobese diabetic mice by a dipeptidyl peptidase IV inhibitor," Endocrinology, vol. 151, no. 7, pp. 3049-3060, 2010.

[46] A. S. Akarte, B. P. Srinivasan, S. Gandhi, and S. Sole, "Chronic DPP-IV inhibition with PKF-275-055 attenuates inflammation and improves gene expressions responsible for insulin secretion in streptozotocin induced diabetic rats," European Journal of Pharmaceutical Sciences, vol. 47, no. 2, pp. 456-463, 2012.

[47] Y. Zhang, Y. Chen, J. Cheng, Z. Guo, Y. Lu, and B. Tian, “DPP IV inhibitor suppresses STZ-induced islets injury dependent on activation of the IGFR/Akt/mTOR signaling pathways by GLP1 in monkeys," Biochemical and Biophysical Research Communications, vol. 456, no. 1, pp. 139-144, 2015.

[48] U. Pugazhenthi, K. Velmurugan, A. Tran, G. Mahaffey, and S. Pugazhenthi, "Anti-inflammatory action of exendin-4 in human islets is enhanced by phosphodiesterase inhibitors: potential therapeutic benefits in diabetic patients," Diabetologia, vol. 53, no. 11, pp. 2357-2368, 2010.

[49] S. R. Cechin, I. Pérez-Álvarez, E. Fenjves et al., "Antiinflammatory properties of exenatide in human pancreatic islets," Cell Transplantation, vol. 21, no. 4, pp. 633-648, 2012.

[50] H. Kanda, S. Tateya, Y. Tamori et al., "MCP-1 contributes to macrophage infiltration into adipose tissue, insulin resistance, and hepatic steatosis in obesity," The Journal of Clinical Investigation, vol. 116, no. 6, pp. 1494-1505, 2006.

[51] S. P. Weisberg, D. Hunter, R. Huber et al., "CCR2 modulates inflammatory and metabolic effects of high-fat feeding," Journal of Clinical Investigation, vol. 116, no. 1, pp. 115-124, 2006.

[52] S. Winer, Y. Chan, G. Paltser et al., "Normalization of obesityassociated insulin resistance through immunotherapy," Nature Medicine, vol. 15, no. 8, pp. 921-929, 2009.

[53] T. M. Jensen, K. Saha, and W. M. Steinberg, "Is there a link between liraglutide and pancreatitis? A post hoc review of pooled and patient-level data from completed liraglutide type 2 diabetes clinical trials," Diabetes Care, vol. 38, pp. 1058-1066, 2015.

[54] A. S. Franks, P. H. Lee, and C. M. George, "Pancreatitis: a potential complication of liraglutide?" Annals of Pharmacotherapy, vol. 46, no. 11, pp. 1547-1553, 2012.

[55] P. C. Butler, M. Elashoff, R. Elashoff, and E. A. M. Gale, "A critical analysis of the clinical use of incretin-based therapies: are the GLP-1 therapies safe?" Diabetes Care, vol. 36, no. 7, pp. 2118-2125, 2013.

[56] P. J. Pussinen, K. Tuomisto, P. Jousilahti, A. S. Havulinna, J. Sundvall, and V. Salomaa, "Endotoxemia, immune response to periodontal pathogens, and systemic inflammation associate with incident cardiovascular disease events," Arteriosclerosis, Thrombosis, and Vascular Biology, vol. 27, no. 6, pp. 1433-1439, 2007.

[57] C. J. Kelly, S. P. Colgan, and D. N. Frank, "Of microbes and meals: the health consequences of dietary endotoxemia," Nutrition in Clinical Practice, vol. 27, no. 2, pp. 215-225, 2012.

[58] J. Frostegård, "Immunity, atherosclerosis and cardiovascular disease," BMC Medicine, vol. 11, article 117, 2013.

[59] K. C. Dozier, E. L. Cureton, R. O. Kwan, B. Curran, J. Sadjadi, and G. P. Victorino, "Glucagon-like peptide-1 protects mesenteric endothelium from injury during inflammation," Peptides, vol. 30, no. 9, pp. 1735-1741, 2009. 
[60] N. M. Krasner, Y. Ido, N. B. Ruderman, and J. M. Cacicedo, "Glucagon-Like Peptide-1 (GLP-1) analog liraglutide inhibits endothelial cell inflammation through a calcium and AMPK dependent mechanism," PLoS ONE, vol. 9, no. 5, Article ID e97554, 2014.

[61] Y. Hattori, T. Jojima, A. Tomizawa et al., "A glucagon-like peptide-1 (GLP-1) analogue, liraglutide, upregulates nitric oxide production and exerts anti-inflammatory action in endothelial cells," Diabetologia, vol. 53, no. 10, pp. 2256-2263, 2010.

[62] A. Shiraki, J.-I. Oyama, H. Komoda et al., "The glucagon-like peptide 1 analog liraglutide reduces TNF- $\alpha$-induced oxidative stress and inflammation in endothelial cells," Atherosclerosis, vol. 221, no. 2, pp. 375-382, 2012.

[63] Y. Wang, E. T. Parlevliet, J. J. Geerling et al., "Exendin-4 decreases liver inflammation and atherosclerosis development simultaneously by reducing macrophage infiltration," British Journal of Pharmacology, vol. 171, no. 3, pp. 723-734, 2014.

[64] Y. Dai, D. Dai, X. Wang, Z. Ding, and J. L. Mehta, "DPP-4 inhibitors repress NLRP3 inflammasome and interleukin-1beta via GLP-1 receptor in macrophages through protein kinase C pathway," Cardiovascular Drugs and Therapy, vol. 28, no. 5, pp. 425-432, 2014.

[65] H. M. Salim, D. Fukuda, Y. Higashikuni et al., "Dipeptidyl peptidase-4 inhibitor, linagliptin, ameliorates endothelial dysfunction and atherogenesis in normoglycemic apolipoproteinE deficient mice," Vascular Pharmacology, vol. 79, pp. 16-23, 2015.

[66] Y. Zeng, C. Li, M. Guan et al., "The DPP-4 inhibitor sitagliptin attenuates the progress of atherosclerosis in apolipoproteinE-knockout mice via AMPK- and MAPK-dependent mechanisms," Cardiovascular Diabetology, vol. 13, article 32, 2014.

[67] S. Tang, Q. Zhang, H. Tang et al., "Effects of glucagon-like peptide-1 on advanced glycation endproduct-induced aortic endothelial dysfunction in streptozotocin-induced diabetic rats: possible roles of Rho kinase- and AMP kinase-mediated nuclear factor $\kappa \mathrm{B}$ signaling pathways," Endocrine, pp. 1-10, 2016.

[68] J. Matsubara, S. Sugiyama, K. Sugamura et al., "A dipeptidyl peptidase-4 inhibitor, des-fluoro-sitagliptin, improves endothelial function and reduces atherosclerotic lesion formation in apolipoprotein E-deficient mice," Journal of the American College of Cardiology, vol. 59, no. 3, pp. 265-276, 2012.

[69] K. Akita, K. Isoda, K. Shimada, and H. Daida, "Dipeptidylpeptidase- 4 inhibitor, alogliptin, attenuates arterial inflammation and neointimal formation after injury in low-density lipoprotein (LDL) receptor-deficient mice," Journal of the American Heart Association, vol. 4, no. 3, Article ID e001469, 2015.

[70] M. Burgmaier, A. Liberman, J. Möllmann et al., "Glucagonlike peptide-1 (GLP-1) and its split products GLP-1(9-37) and GLP-1(28-37) stabilize atherosclerotic lesions in apoe $e^{-/-}$mice," Atherosclerosis, vol. 231, no. 2, pp. 427-435, 2013.

[71] M. Lappas, "Anti-inflammatory properties of sirtuin 6 in human umbilical vein endothelial cells," Mediators of Inflammation, vol. 2012, Article ID 597514, 11 pages, 2012.

[72] X. Du, X. Hu, and J. Wei, "Anti-inflammatory effect of exendin-4 postconditioning during myocardial ischemia and reperfusion," Molecular Biology Reports, vol. 41, no. 6, pp. 3853-3857, 2014.

[73] Y. Cai, X. Hu, B. Yi, T. Zhang, and Z. Wen, "Glucagonlike peptide-1 receptor agonist protects against hyperglycemiainduced cardiocytes injury by inhibiting high mobility group box 1 expression," Molecular Biology Reports, vol. 39, no. 12, pp. 10705-10711, 2012.
[74] Y.-S. Liu, Z.-W. Huang, L. Wang et al., "Sitagliptin alleviated myocardial remodeling of the left ventricle and improved cardiac diastolic dysfunction in diabetic rats," Journal of Pharmacological Sciences, vol. 127, no. 3, pp. 260-274, 2015.

[75] M. L. Block and J.-S. Hong, "Microglia and inflammationmediated neurodegeneration: multiple triggers with a common mechanism," Progress in Neurobiology, vol. 76, no. 2, pp. 77-98, 2005.

[76] E. G. McGeer and P. L. McGeer, "The role of anti-inflammatory agents in Parkinson's disease," CNS Drugs, vol. 21, no. 10, pp. 789-797, 2007.

[77] R. E. Mrak and W. S. T. Griffin, "Glia and their cytokines in progression of neurodegeneration," Neurobiology of Aging, vol. 26, no. 3, pp. 349-354, 2005.

[78] E. M. C. Schrijvers, J. C. M. Witteman, E. J. G. Sijbrands, A. Hofman, P. J. Koudstaal, and M. M. B. Breteler, "Insulin metabolism and the risk of Alzheimer disease: the Rotterdam Study," Neurology, vol. 75, no. 22, pp. 1982-1987, 2010.

[79] C. Kappe, L. M. Tracy, C. Patrone, K. Iverfeldt, and Å. Sjöholm, "GLP-1 secretion by microglial cells and decreased CNS expression in obesity," Journal of Neuroinflammation, vol. 9, article 276, 2012.

[80] T. Perry and N. H. Greig, "Enhancing central nervous system endogenous GLP-1 receptor pathways for intervention in Alzheimer's disease," Current Alzheimer Research, vol. 2, no. 3, pp. 377-385, 2005.

[81] C. Holscher, "Incretin analogues that have been developed to treat type 2 diabetes hold promise as a novel treatment strategy for Alzheimer's disease," Recent Patents on CNS Drug Discovery, vol. 5, no. 2, pp. 109-117, 2010.

[82] A. Harkavyi and P. S. Whitton, "Glucagon-like peptide 1 receptor stimulation as a means of neuroprotection," British Journal of Pharmacology, vol. 159, no. 3, pp. 495-501, 2010.

[83] A. Hamilton and C. Hölscher, "Receptors for the incretin glucagon-like peptide-1 are expressed on neurons in the central nervous system," NeuroReport, vol. 20, no. 13, pp. 1161-1166, 2009.

[84] A. Hamilton, S. Patterson, D. Porter, V. A. Gault, and C. Holscher, "Novel GLP-1 mimetics developed to treat type 2 diabetes promote progenitor cell proliferation in the brain," Journal of Neuroscience Research, vol. 89, no. 4, pp. 481-489, 2011.

[85] K. Hunter and C. Hölscher, "Drugs developed to treat diabetes, liraglutide and lixisenatide, cross the blood brain barrier and enhance neurogenesis," BMC Neuroscience, vol. 13, article 33, 2012.

[86] P. L. Mcclean, V. Parthsarathy, E. Faivre, and C. Holscher, "The diabetes drug liraglutide prevents degenerative processes in a mouse model of Alzheimer's disease," The Journal of Neuroscience, vol. 31, no. 17, pp. 6587-6594, 2011.

[87] N. Gong, Q. Xiao, B. Zhu et al., "Activation of spinal glucagonlike peptide-1 receptors specifically suppresses pain hypersensitivity," Journal of Neuroscience, vol. 34, no. 15, pp. 5322-5334, 2014.

[88] K. Plaschke and S. Hoyer, "Action of the diabetogenic drug streptozotocin on glycolytic and glycogenolytic metabolism in adult rat brain cortex and hippocampus," International Journal of Developmental Neuroscience, vol. 11, no. 4, pp. 477-483, 1993.

[89] V. Solmaz, B. P. Çınar, G. Yiğittürk, T. Çavuşoğlu, D. Taşkıran, and O. Erbaş, "Exenatide reduces TNF- $\alpha$ expression and improves hippocampal neuron numbers and memory in streptozotocin treated rats," European Journal of Pharmacology, vol. 765 , pp. 482-487, 2015. 
[90] T. Iwai, T. Sawabe, K. Tanimitsu, M. Suzuki, S. Sasaki-Hamada, and J.-I. Oka, "Glucagon-like peptide-1 protects synaptic and learning functions from neuroinflammation in rodents," Journal of Neuroscience Research, vol. 92, no. 4, pp. 446-454, 2014.

[91] P. L. McClean and C. Hölscher, "Liraglutide can reverse memory impairment, synaptic loss and reduce plaque load in aged APP/PS1 mice, a model of Alzheimer's disease," Neuropharmacology, vol. 76, pp. 57-67, 2014.

[92] C. Hölscher, “The incretin hormones glucagonlike peptide 1 and glucose-dependent insulinotropic polypeptide are neuroprotective in mouse models of Alzheimer's disease," Alzheimer's \& Dementia, vol. 10, no. 1, pp. S47-S54, 2014.

[93] M. D’Amico, C. Di Filippo, R. Marfella et al., "Long-term inhibition of dipeptidyl peptidase- 4 in Alzheimer's prone mice," Experimental Gerontology, vol. 45, no. 3, pp. 202-207, 2010.

[94] S. Kim, M. Moon, and S. Park, "Exendin-4 protects dopaminergic neurons by inhibition of microglial activation and matrix metalloproteinase- 3 expression in an animal model of Parkinson's disease," The Journal of Endocrinology, vol. 202, no. 3, pp. 431-439, 2009.

[95] J. Lee, S.-W. Hong, S. W. Chae et al., "Exendin-4 improves steatohepatitis by increasing Sirtl expression in high-fat dietinduced obese C57BL/6J mice," PLoS ONE, vol. 7, no. 2, Article ID e31394, 2012.

[96] F. Xu, Z. Li, X. Zheng et al., "SIRT1 mediates the effect of GLP1 receptor agonist exenatide on ameliorating hepatic steatosis," Diabetes, vol. 63, no. 11, pp. 3637-3646, 2014.

[97] Y. Eguchi, Y. Kitajima, H. Hyogo et al., "Pilot study of liraglutide effects in non-alcoholic steatohepatitis and non-alcoholic fatty liver disease with glucose intolerance in Japanese patients (LEAN-J)," Hepatology Research, vol. 45, no. 3, pp. 269-278, 2015.

[98] G. Derosa, I. G. Franzetti, F. Querci et al., "Exenatide plus metformin compared with metformin alone on $\beta$-cell function in patients with Type 2 diabetes," Diabetic Medicine, vol. 29, no. 12, pp. 1515-1523, 2012.

[99] M. Saraheimo, A.-M. Teppo, C. Forsblom, J. Fagerudd, and P.H. Groop, "Diabetic nephropathy is associated with low-grade inflammation in Type 1 diabetic patients," Diabetologia, vol. 46, no. 10, pp. 1402-1407, 2003.

[100] C. D. A. Stehouwer, M.-A. Gall, J. W. R. Twisk, E. Knudsen, J. J. Emeis, and H.-H. Parving, "Increased urinary albumin excretion, endothelial dysfunction, and chronic low-grade inflammation in type 2 diabetes: progressive, interrelated, and independently associated with risk of death," Diabetes, vol. 51, no. 4, pp. 1157-1165, 2002.

[101] R. Kodera, K. Shikata, H. U. Kataoka et al., "Glucagon-like peptide-1 receptor agonist ameliorates renal injury through its anti-inflammatory action without lowering blood glucose level in a rat model of type 1 diabetes," Diabetologia, vol. 54, no. 4, pp. 965-978, 2011.

[102] P. Schlatter, C. Beglinger, J. Drewe, and H. Gutmann, "Glucagon-like peptide 1 receptor expression in primary porcine proximal tubular cells," Regulatory Peptides, vol. 141, no. 1-3, pp. 120-128, 2007.

[103] S. Sancar-Bas, S. Gezginci-Oktayoglu, and S. Bolkent, "Exendin- 4 attenuates renal tubular injury by decreasing oxidative stress and inflammation in streptozotocin-induced diabetic mice," Growth Factors, vol. 33, no. 5-6, pp. 419-429, 2015.

[104] M. Gangadharan Komala, S. Gross, A. Zaky, C. Pollock, and U. Panchapakesan, "Saxagliptin reduces renal tubulointerstitial inflammation, hypertrophy and fibrosis in diabetes," Nephrology, 2015.

[105] R. Kodera, K. Shikata, T. Takatsuka et al., "Dipeptidyl peptidase4 inhibitor ameliorates early renal injury through its antiinflammatory action in a rat model of type 1 diabetes," Biochemical and Biophysical Research Communications, vol. 443, no. 3, pp. 828-833, 2014.

[106] S. Nakashima, T. Matsui, M. Takeuchi, and S.-I. Yamagishi, "Linagliptin blocks renal damage in type 1 diabetic rats by suppressing advanced glycation end products-receptor axis," Hormone and Metabolic Research, vol. 46, no. 10, pp. 717-721, 2014.

[107] Y. Higashijima, T. Tanaka, J. Yamaguchi, S. Tanaka, and M. Nangaku, "Anti-inflammatory role of DPP-4 inhibitors in a nondiabetic model of glomerular injury," The American Journal of Physiology-Renal Physiology, vol. 308, no. 8, pp. F878-F887, 2015.

[108] D. Katagiri, Y. Hamasaki, K. Doi et al., "Protection of glucagonlike peptide-1 in cisplatin-induced renal injury elucidates gutkidney connection," Journal of the American Society of Nephrology, vol. 24, no. 12, pp. 2034-2043, 2013.

[109] Y.-T. Chen, T.-H. Tsai, C.-C. Yang et al., "Exendin-4 and sitagliptin protect kidney from ischemia-reperfusion injury through suppressing oxidative stress and inflammatory reaction," Journal of Translational Medicine, vol. 11, article 270, 2013.

[110] T. Zhu, X.-L. Wu, W. Zhang, and M. Xiao, "Glucagon like peptide-1 (GLP-1) modulates OVA-induced airway inflammation and mucus secretion involving a protein kinase A (PKA)dependent nuclear factor- $\kappa \mathrm{B}(\mathrm{NF}-\kappa \mathrm{B})$ signaling pathway in mice," International Journal of Molecular Sciences, vol. 16, no. 9, pp. 20195-20211, 2015.

[111] E. Zhang, F. Xu, H. Liang et al., "GLP-1 receptor agonist exenatide attenuates the detrimental effects of obesity on inflammatory profile in testis and sperm quality in mice," American Journal of Reproductive Immunology, vol. 74, no. 5, pp. 457-466, 2015.

[112] H. W. Bakos, R. C. Henshaw, M. Mitchell, and M. Lane, "Paternal body mass index is associated with decreased blastocyst development and reduced live birth rates following assisted reproductive technology," Fertility and Sterility, vol. 95, no. 5, pp. 1700-1704, 2011.

[113] D. J. Drucker and C. F. Rosen, "Glucagon-like peptide-1 (GLP1) receptor agonists, obesity and psoriasis: diabetes meets dermatology," Diabetologia, vol. 54, no. 11, pp. 2741-2744, 2011.

[114] A. Faurschou, F. K. Knop, J. P. Thyssen, C. Zachariae, L. Skov, and T. Vilsbøll, "Improvement in psoriasis after treatment with the glucagon-like peptide-1 receptor agonist liraglutide," Acta Diabetologica, vol. 51, no. 1, pp. 147-150, 2014.

[115] S. Steven, M. Hausding, S. Kröller-Schön et al., "Gliptin and GLP-1 analog treatment improves survival and vascular inflammation/dysfunction in animals with lipopolysaccharide-induced endotoxemia," Basic Research in Cardiology, vol. 110, no. 2, article 6, 2015. 


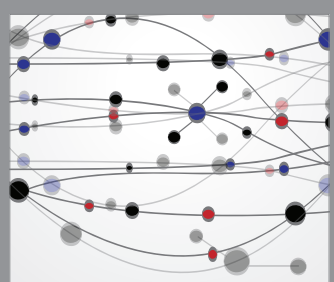

The Scientific World Journal
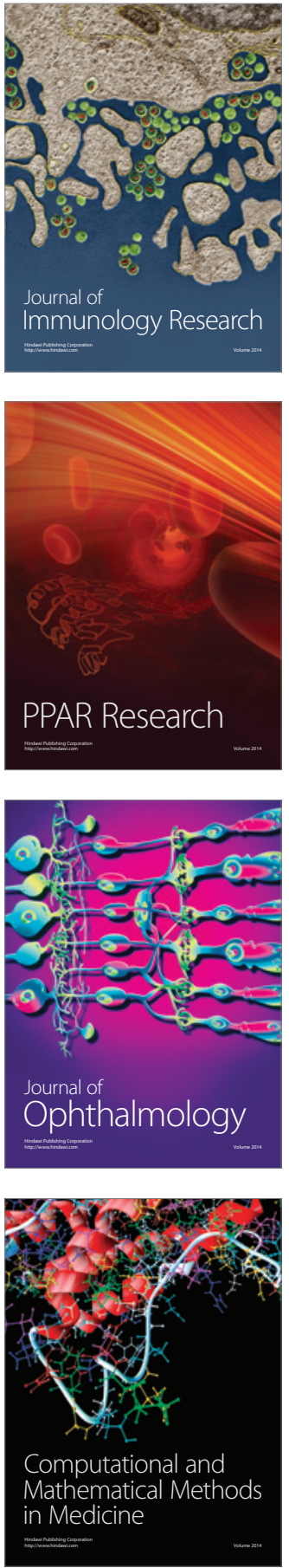

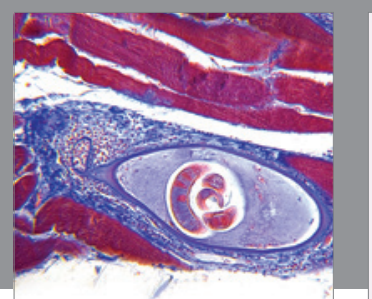

Gastroenterology Research and Practice

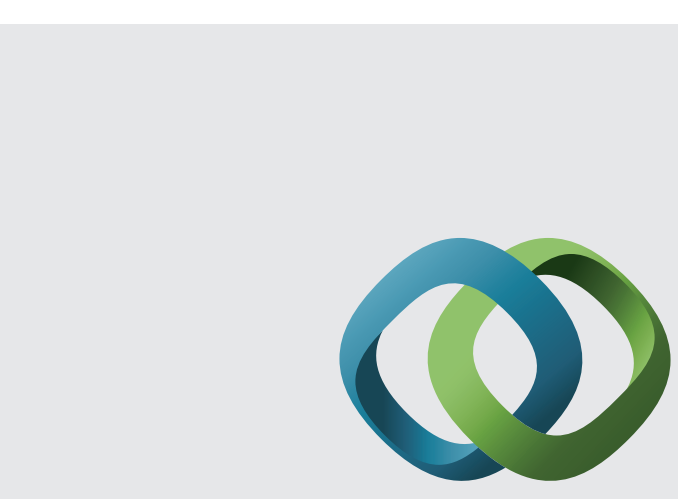

\section{Hindawi}

Submit your manuscripts at

http://www.hindawi.com
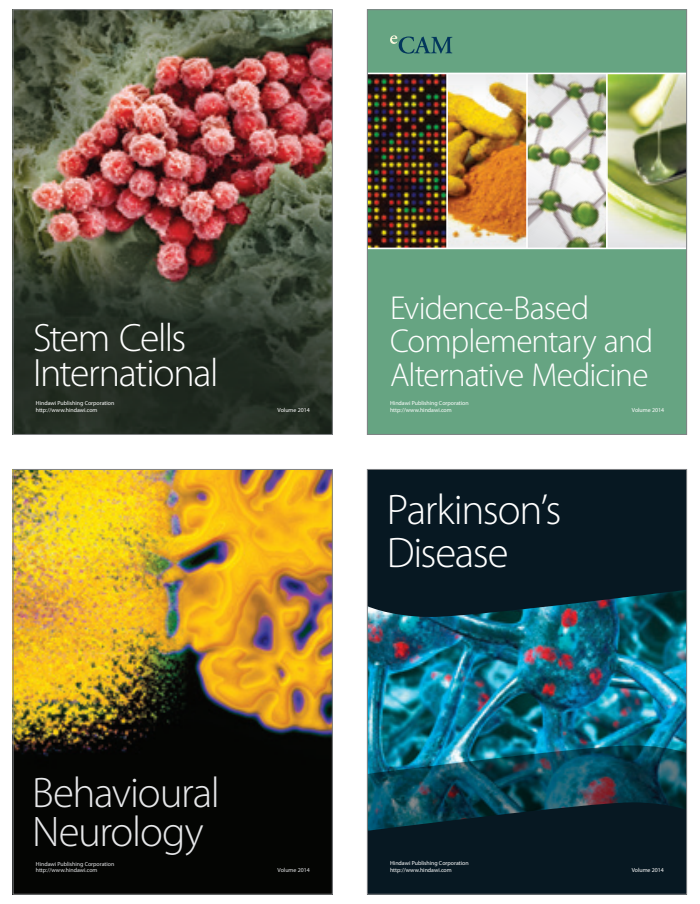
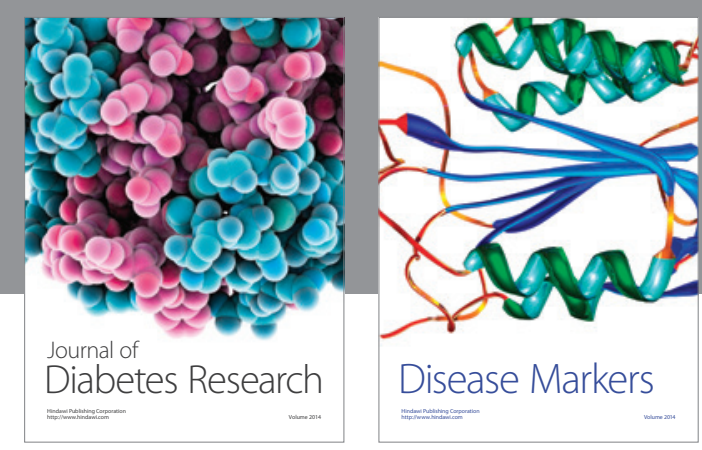

Disease Markers
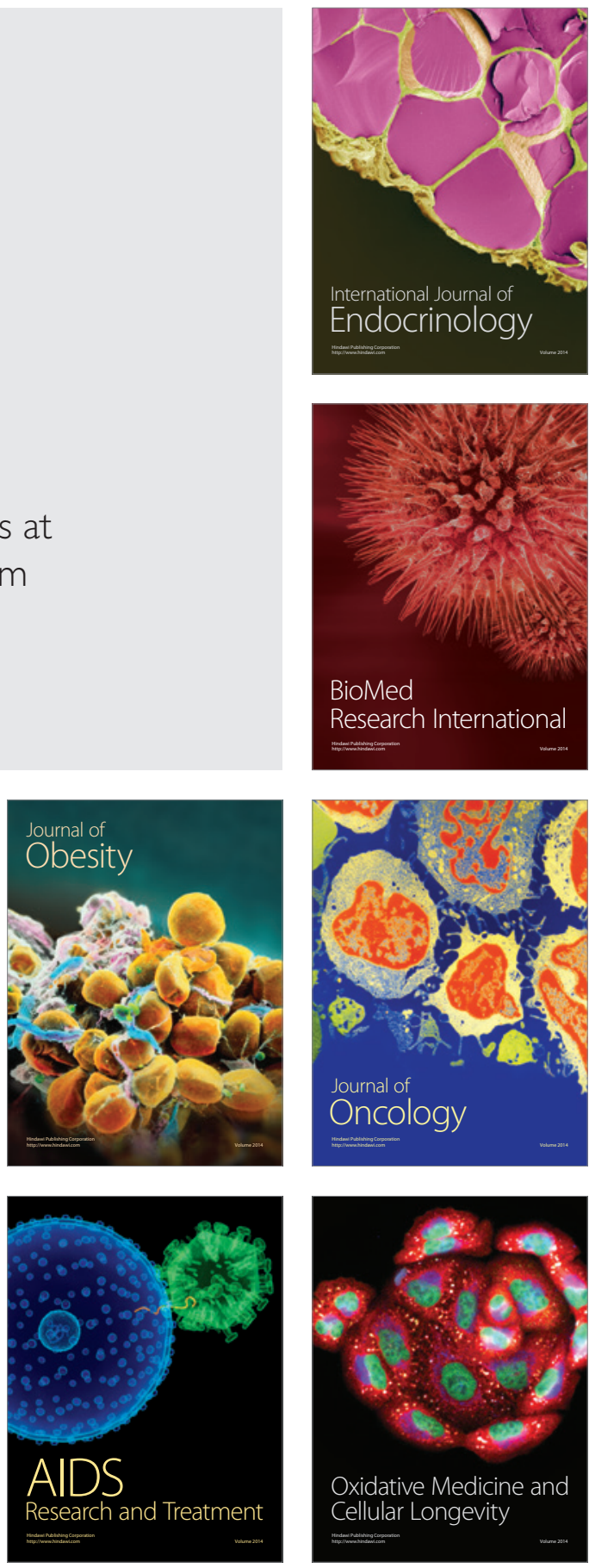